\title{
EDUCAÇÃO DE JOVENS E ADULTOS A DISTÂNCIA: IMPEDIMENTOS E SUPERAÇÕES
}

\author{
Geraldo Ananias Reis (UnB)* \\ http://orcid.org/0000-0001-7871-5880 \\ Carlos Lopes $(\mathrm{UnB})^{* *}$ \\ http://orcid.org/0000-0003-2745-3942
}

\section{RESUMO}

0 artigo analisa as trajetórias de quatro egressos de uma instituição pública: o Centro de Educação de Jovens e Adultos da Asa Sul (CESAS), em Brasília, DF, em curso a distância. Apreende a origem social dos egressos, o capital cultural, as dificuldades, limitações e opção pela EaD. Como o capital cultural e as imposições das condições de vida dos egressos da EJA/EaD impulsionaram o retorno aos estudos? A resposta a essa questão, em um enfoque descritivo e exploratório, em conexão com os dados de entrevistas, dialoga com Bourdieu e Lahire, concluindo: os egressos da EJA, com exceção de um, têm origem familiar com posição social homóloga e baixo capital cultural institucionalizado; imposições estruturais provocam a prioridade do trabalho e não do capital cultural institucionalizado e, em outro momento da trajetória, o trabalho influencia o retorno aos estudos. Esse regresso, via EJA/EaD, dá aos sujeitos um sentimento de valoração, principalmente, por possibilitar conciliar trabalho e estudo, tendo a escolha um sentido prático.

Palavras-chave: Educação de jovens e adultos. Educação a distância. Escolarização. Capital cultural.

\section{ABSTRACT \\ EDUCATION OF YOUNG PEOPLE AND ADULTS: IMPEDIMENTS AND OVERCOMING}

The article analyzes the trajectories of four graduates of a public institution: the Center for Youth and Adult Education in Asa Sul (CESAS), in Brasília-DF, in a distance-learning course (EaD). It apprehends the social origin of the graduates, the cultural capital, the difficulties, limits and option for EaD. How did the cultural capital and the impositions of the living conditions of EJA/ EaD graduates boost their return to studies? The answer to this question, in a descriptive and exploratory approach, in connection with interviews data, dialogues with Bourdieu and Lahire, concluding: the EJA alumni, except for one,

Mestre em Educação pela Faculdade de Educação da Universidade de Brasília (UnB). Professor da Secretaria de Estado de Educação do Distrito Federal (SEEDF). Membro do Grupo de Pesquisa Educação a Distância: Agentes e Estruturas na Perspectiva Sociológica da Educação. E-mail: geraldoananias@gmail.com

** Doutor em Sociologia pela Pontifícia Universidade Católica de São Paulo (PUC-SP). Professor Associado da Faculdade de Educação da Universidade de Brasília (FE/UnB). Docente do Programa de Pós-Graduação em Educação da Universidade de Brasília (PPGE/UnB). Coordenador do Grupo de Pesquisa Educação a Distância: Agentes e Estruturas na Perspectiva Sociológica da Educação. E-mail: carloslopes@unb.br 
have family origins with homologous social position and low institutionalized cultural capital; structural impositions provoke the prioritization of work and not of the institutionalized cultural capital and, in another moment of the trajectory, work influences the return to studies. This return, through EJA / EaD, gives the subjects a sense of appreciation, mainly by making it possible to reconcile work and study, with this choice having a practical meaning.

Keywords: Education of young people and adults. Distance learning. Schooling. Cultural capital.

\section{RESUMEN}

\section{LA EDUCACIÓN A DISTANCIA DE JÓVENES Y ADULTOS: IMPEDIMENTOS Y SUPERACIONES}

El artículo analiza las trayectorias de estudiantes graduados de la institución pública Centro de Educación de Jóvenes y Adultos del Ala Sur (CESAS), en Brasilia-DF, curso de modalidad a distancia. Desde un énfasis exploratorio, el análisis de las narrativas lleva a cabo la interpretación heurística a la luz de autores como Bourdieu, Lahire y otros. A pesar de los graduados haberse enfrentado a las mismas imposiciones estructurales - educación formal completa para posicionarse mejor en el mercado laboral; haber experimentado un aplazamiento de acciones que se podrían haber hecho en un momento más apropiado y por lo tanto enfrentarse a la necesidad de compensar este momento - las singularidades individuales permanecieron, asimilándose subjetivamente una serie de influencias. Los agentes de clases más bajas, encuentran en el acceso a la escuela capital cultural, aún cuando sólo se trate e capital institucionalizado, lo que les permita mejores condiciones para entrar en un mercado laboral tan parcial y excluyente.

Palabras clave: Educación de jóvenes y adultos. Educación a distancia. Escolarización. Capital cultural.

\section{Introdução}

Criar e garantir possibilidades de acesso e permanência no sistema educacional pode criar condições para a transposição do abismo da desigualdade e da baixa escolaridade. É imperioso que se garanta possibilidades de uma educação que venha se somar aos interesses de sujeitos que há muito vêm sendo privados do direito de se escolarizar e que assegure o acesso ao saber formal, reconhecendo-o como um elemento primordial para o exercício da cidadania. A educação é um bem essencial de qualquer sociedade comprometida com a prevenção de situações de risco, de abuso de direitos e de enfrentamento às situações de pobreza. Montesinos (1997, p. 85) estabelece conexão entre os aspectos econômicos, a educação e a desigualdade: "Diferenças na distribuição da renda, na qualidade de vida, no acesso às oportunidades, no exercício do direito a uma educação de igual qualidade e na proteção dos abusos do poder, propiciam a desigualdade."

A exclusão social no Brasil se reflete no seu sistema educacional, que mantém milhões de pessoas fora das salas de aula, uma parte significativa da população sem acesso à escola e nem condições de permanência nela. A história da educação escolar no Brasil aponta para um longo caminho de exclusão. Parte da população vem sendo impedida de usufruir um direito juridicamente garantido há décadas, são as 
minorias: ${ }^{1}$ índios, negros, mulheres, travestis, pobres que não adentram a escola e, se o fazem, não permanecem por muito tempo. De acordo com Andrade (2004), essa exclusão reflete os empecilhos e as dificuldades de acesso aos direitos da cidadania. Esse impedimento produz misérias, o desemprego, a periferização, os sem-terra, os sem-teto. Faz-se necessário pensar um projeto educacional que dê acesso, permanência, aprendizado efetivo e de qualidade, que proporcione aos cidadãos consciência de seu lugar social e conhecimento de seus direitos. Para Abdalla (2004, p. 194),

[...] se o fracasso escolar é uma produção inscrita em uma possibilidade de vida, para desmanchá-lo, outra possibilidade de vida terá de ser inventada. Construir saídas é inventar novas entradas, novos questionamentos e experiências. Se quisermos outras experiências educativas são outras práticas que devem ser fabricadas.

São muitos os estudos que abordam a EJA, tratam de sua importância histórico-social, dos múltiplos aspectos da evasão e do abandono dos estudos. Nosso artigo tem especificidade em relação ao estudo de egressos da EJA/EaD, concluintes do seu terceiro segmento. 2

0 artigo analisa as trajetórias de egressos de uma instituição pública: o Centro de Educação de Jovens e Adultos da Asa Sul (CESAS), em Brasília, DF, em curso a distância, apreendendo os traços da origem social dos egressos, o capital cultural do grupo familiar, as suas dificuldades, limitações e opção pela EaD. Toma a seguinte questão como pesquisa: como o capital cultural e as imposições das condições de vida dos egressos da EJA/EaD se situaram em suas trajetórias, impulsionando o retorno aos estudos? A escolha do CESAS se deu por ser a única na rede pública de ensino do Distrito

1 "O conceito contemporâneo de minoria se refere à possibilidade de terem voz ativa ou intervirem nas instâncias decisórias do Poder aqueles setores ou frações de classe comprometidas com as diversas modalidades de luta assumidas pela questão social. Por isso, são consideradas minorias os negros, os homossexuais, as mulheres, os povos indígenas, os ambientalistas, os antineoliberalistas etc." (SODRÉ, 2006, p. 44).

20 terceiro segmento equivale ao Ensino Médio.
Federal que oferecia à época da pesquisa a EJA na modalidade EaD. ${ }^{3}$

Delimitar os egressos como os sujeitos da pesquisa também trouxe desafios à operacionalização do estudo. Desafios no sentido da identificação e acesso aos egressos e o aceite deles em participar da pesquisa. Para tanto, foi necessário engendrar levantamentos em sítios da internet e em redes sociais, por exemplo, para a localização, contato e sensibilização para a participação dos egressos na investigação. Da identificação nominal de 120 egressos, foi possível ter adesão à pesquisa de quatro ex-estudantes da instituição. ${ }^{4}$

A pesquisa se situa ${ }^{5}$ no âmbito de uma proposta de educação voltada às necessidades educacionais do público da EJA que teve a escolarização interrompida. Com enfoque qualitativo, parte de uma abordagem interpretativa e busca entender, ou interpretar, os fenômenos em termos dos significados que as pessoas a eles conferem (DENZIN; LINCOLN, 2006).

\section{A educação de jovens e adultos a distância e seus sujeitos}

A educação é direito do cidadão e é dever do Estado garantir o acesso à escola. A oferta de uma educação acessível e de qualidade deve dar condições para que todos se capacitem para a vida. A escola deve possibilitar desenvolvimento humano capaz de fazer recuar a pobreza, a exclusão social e as opressões (BUARQUE, 1997).

3 Esse texto é um desdobramento de um dos resultados da investigação desenvolvida no Grupo de Pesquisa Educação a Distância: Agentes e Estruturas na Perspectiva Sociológica da Educação, no Programa de Pós-Graduação em Educação (FE/PPGE-UnB), em trabalho sob o título "Jovens e Adultos na Educação a Distância: uma perspectiva disposiconalista" (REIS, 2014), sendo revisto e ajustado para o formato de artigo.

4 Foram observados os aspectos éticos em relação à pesquisa, obtendo a assinatura dos sujeitos da pesquisa, no Termo de Consentimento Livre e Esclarecido, ficando uma cópia com os entrevistados.

5 Não é nosso objetivo fazer exposição do modelo pedagógico do curso a distância para EJA, mas apenas referenciar no artigo a modalidade em si. 
A Constituição Federal de 1988 garante a educação para todos. A EJA, nesse contexto, assume um papel significativo ao colaborar para o acesso e a permanência na escola e para ampliar a oferta de conhecimentos que contribuam com a emancipação do sujeito (BRASIL, 2009). Portanto,

[...] a EJA volta-se para um conjunto amplo e heterogêneo de jovens e adultos oriundos de diferentes frações da classe trabalhadora. Por isso, é compreendida na diversidade e multiplicidade de situações relativas às questões étnico-racial, de gênero, geracionais; de aspectos culturais e regionais e geográficos; de orientação sexual; de privação da liberdade; e de condições mentais, físicas e psíquicas. (BRASIL, 2009, p. 28).

O sujeito da EJA vem de um contexto de diversidade sociocultural e essa heterogeneidade é um fator relevante para a elaboração de seu currículo. A Lei n 9.394/1996 - Lei de Diretrizes e Bases da Educação Nacional (LDB), em seu artigo $4^{\circ}$, destaca o dever do Estado com a educação pública mediante a garantia do Ensino Fundamental, obrigatório e gratuito, até mesmo para aqueles que não tiveram acesso a ele na idade considerada própria. Por isso, nesse contexto, a escolarização de jovens e adultos é um primeiro passo na conquista do direito a educar-se; a participar da construção democrática; de ingressar no âmbito da ciência e da tecnologia, permitindo novas formas e estruturas de pensamento e de conhecimento; de suporte às possibilidades de comunicação, inserção social e de cidadania das pessoas (RIVERO, 2009; FÁVERO, 2009) ${ }^{6}$. Em suma, tal tarefa exige promover, na concepção e estratégias de ação, iniciativas que, unidas a outros fatores socioeconômicos e políticos, se orientem para romper a pobreza, sendo tarefa prioritária "se admitimos que a condição analfabeta não apenas é expressão da pobreza, mas de impedimento de superá-la e para alentar e

6 Os textos de Rivero (2009) e Fávero (2009) constam em livro patrocinado pela Unesco e Fundação Santillana, sendo esses apresentados como autores na capa da publicação, mas com artigos separados e com algumas ideias convergentes no que tange à educação de jovens e adultos, como direito, cidadania e mudança na realidade. acompanhar a educação dos filhos [...]." (RIVER0, 2009, p. 50).

A Educação de Jovens e Adultos na modalidade a distância - EJA/EaD - surge como uma possibilidade de ampliar e facilitar o acesso à educação aos sujeitos que foram impedidos de se escolarizar. Além disso, "a evolução técnica possibilita o despertar e a ampliação da sensibilidade perceptiva e cognitiva. E oferece novas condições de apropriação e recepção de representações e conhecimentos sobre o mundo." (SETTON, 2005, p. 88).

Segundo Lobo Neto (2006), o ponto principal sobre EaD é a possibilidade que ela traz de ampliação do acesso a uma educação de qualidade, a oportunidade de relativizar a questão do tempo, de sanar carências quantitativas e qualitativas de instituições educacionais e por ser um instrumento eficaz de renovação de modelos pedagógicos.

A EaD, mediada pelas Tecnologias da Informação e Comunicação (TIC), apresenta uma nova possibilidade de interação e de ensino ao permitir que haja comunicação virtual sincrônica ou diacrônica. 0 ambiente virtual de aprendizagem, ao integrar conteúdos e sujeitos, possibilita a presencialidade, a comunicação, a expressão e a autoria (SANTOS, 2011). Nessa perspectiva,

A comunicação por meio da TIC caracteriza-se como uma nova modalidade comunicacional que permite romper com a linearidade e a unidirecionalidade entre emissor e receptor e potencializa a comunicação multidirecional pela criação de redes formadas na diversidade de informações, recurso e intervenções. (ALMEIDA, 2006, p. 206).

A história da educação e da escola no Brasil revela a exclusão de uma parcela expressiva da população. Neste contexto, os projetos de Educação de Jovens e Adultos se apresentam como proposta que visa garantir o direito à educação que vem sendo negado a tantos jovens, adultos e idosos (DUARTE, 2012). Dentre os estudantes da EJA, muitos nunca frequentaram a escola, outros aprenderam os rudimentos do letramento, mas se viram obrigados a interromper 
os estudos por causa das necessidades de trabalho, questões da vida familiar ou social. Ao discorrer sobre esses jovens e adultos, deve-se considerar que são sujeitos excluídos da escola, pessoas já inseridas no mundo do trabalho e que apresentam uma trajetória de vida rica em experiências, conhecimentos acumulados e reflexões sobre si mesmo e sobre o mundo (OLIVEIRA, 1999).

A oferta de EJA precisa ser pensada como um compromisso social e político que deve estar em consonância com uma proposta de educar para o empoderamento de grupos sociais desfavorecidos e para a superação de uma sociedade segregadora e geradora de pobreza no Brasil.

\section{Contribuições de Pierre Bourdieu e Bernard Lahire}

Neste estudo apresentamos alguns elementos do debate Bourdieu e Lahire, para projetar a compreensão dos aspectos significativos das trajetórias dos sujeitos que cursaram a EJA na modalidade a distância.

A leitura de Bourdieu permite compreender a reprodução das desigualdades e a distribuição de capital cultural. Este capital se apresenta em três estados: incorporado, sob a forma de qualidades, habilidades, conhecimentos ou disposições que distinguem o sujeito dos demais; objetivado, sob a forma de bens culturais - quadros, livros, obras de arte; e institucionalizado, na forma de títulos e diplomas escolares (BOURDIEU, 2011). Dessa maneira,

[...] o capital cultural é um ter que se tornou ser, uma propriedade que se fez corpo e tornou-se parte integrante da 'pessoa', um habitus. Aquele que o possui 'pagou com sua própria pessoa' e com aquilo que tem de mais pessoal, seu tempo. Esse capital 'pessoal' não pode ser transmitido instantaneamente. [...] Não pode ser acumulado para além das capacidades de apropriação de um agente singular; depaupera e morre com seu portador. (BOURDIEU, 2011, p. 74-75, grifo do autor).
Essa teoria questiona a ideia de que a ampliação da oferta de educação escolar levaria, por si só, à superação das desigualdades sociais e educacionais; de que as diferenças sociais se explicariam pela capacidade individual; e de que a escola seria uma instituição neutra que avaliaria com isenção, contribuindo para o aumento da mobilidade social (NOGUEIRA, 2009). De acordo com Bourdieu, os sujeitos trazem uma herança que adquirem na sua convivência familiar e social e isto os diferencia. São heranças adquiridas ao longo das trajetórias de vida e que se transformam no decurso do processo de socialização e influem, positiva ou negativamente, na trajetória escolar (NOGUEIRA; NOGUEIRA, 2009). Bernard Lahire (2002), analisando os processos de transmissão de capital cultural, afirma que a herança desse capital não se dá espontaneamente. Essa transmissão é um trabalho incessante, diário, de longo alcance e às vezes doloroso, tanto para os filhos quanto para os pais. Segundo Lahire (1997), a transmissão e a herança de capital cultural perdem seu sentido quando confrontados com as análises de socialização familiar e escolar, e seria mais razoável trabalhar com a perspectiva de uma outorga de capital cultural, pois

[...] falar de 'transmissão' é, principalmente, conceber a ação unilateral de um destinador para um destinatário, ao passo que o destinatário contribui para construir a 'mensagem' que se considera ter-lhe sido 'transmitida'. Ele tem de atribuir-lhe sentido na relação social [...] Além disso, mesmo nas mais formais situações de aprendizagem [...], o que o adulto julga 'transmitir' nunca é exatamente aquilo que é 'recebido' pelas crianças. (LAHIRE, 1997, p. 341, grifo do autor).

Para Lahire, esse acervo assimilado pelo sujeito passa a fazer parte de sua subjetividade sob a forma de cultura geral. Esse é o legado familiar que mais tem influência sobre a trajetória escolar dos sujeitos e, relativizando o papel do capital econômico, cabe à sua posse, ou não, a explicação para as disparidades escolares (NOGUEIRA, 2009). Lahire (1997), ao inves- 
tigar o improvável sucesso escolar de sujeitos dos meios populares, busca compreender como alunos, em situações que os predispunham ao fracasso, superaram as dificuldades inerentes à sua origem sociocultural e alcançaram êxito. Então, "como, pode-se questionar, uma família que acumula tantas 'deficiências' poderia levar uma criança a ter 'sucesso' na escola? [...] Como é possível que configurações familiares engendrem, socialmente, crianças com níveis de adaptação escolar tão diferentes?" (LAHIRE, 1997, p. 12-13, grifo do autor).

Para compreender essas particularidades, Lahire (1997) examina o objeto singular, os sujeitos e as modalidades de socialização familiar. Assim, ele se deparou com situações que lhe permitiram compreender a forma como o capital cultural parental podia ser transmitido ou não. Ele constatou que mesmo com a ausência de capital cultural ou com a falta de uma ação espontânea de transmissão deste, os conhecimentos escolares foram apropriados pelos estudantes.

Bourdieu, ao abordar a relação entre as ações dos sujeitos e as estruturas sociais, vai além das explicações objetivistas que as compreendem como uma execução automática de estruturas externas, as quais foram incorporadas e determinam de fora para dentro as práticas individuais. Ele também supera as explicações subjetivistas que consideram essas práticas como um produto consciente, autônomo e intencional dos sujeitos (NOGUEIRA, 2004). Para Bourdieu, as estruturas externas encontram-se interiorizadas no indivíduo, compondo um conjunto de disposições estruturadas que, por sua vez, estruturam as práticas e as representações das práticas dos sujeitos (NOGUEIRA, 2004). Nesta direção, Landini (2007, p. 4)

compreende as disposições como tendências incorporadas pelos atores decorrentes da especificidade do processo de socialização por eles percorrido, particularmente da sua inserção social mais objetiva em determinados campos (religioso, intelectual, científico etc.) que presidem às suas práticas sociais.
Nessa perspectiva, os indivíduos tenderiam a agir de acordo com essas disposições incorporadas, peculiares aos grupos nos quais são socializados, em uma relação dialética entre as estruturas sociais e as disposições estruturadas do agente social: a interiorização da exterioridade e a exteriorização da interioridade (BOURDIEU, 2013).

Assim, o sujeito não é nem o indivíduo isolado, consciente e reflexivo, nem o indivíduo determinado, subordinado às condições objetivas em que vive. Por meio das experiências, os grupos sociais vão adquirindo um conhecimento empírico quanto àquilo que seus membros podem, ou não, alcançar, de acordo com sua realidade social (NOGUEIRA; NOGUEIRA, 2002).

Contudo, a herança social não revoga as diferenças individuais. O sujeito, ao longo da vida, interage com inúmeras experiências sociais que o impressionam e o fazem diverso das demais pessoas do seu grupo de origem; isso o faz atuar de modo peculiar diante das mais variadas situações. Ao contrário do pensamento de Bourdieu, para Lahire o habitus, familiar ou individual, não pode ser depreendido de modo direto do habitus de classe, pois este não se reduz unicamente à posição de classe. O habitus familiar ou individual é consequência de múltiplas influências sociais (LAHIRE, 2009; CHARLOT, 2000 apud NOGUEIRA; NOGUEIRA, 2002). Portanto,

[...] a teoria do habitus como 'sistema de disposições gerais e transponíveis' não permite levar em consideração toda a variação do que denomino 'patrimônios individuais de disposições e competências'. Habitus como 'a fórmula geradora das práticas' é muito homogeneizante. Os atores são portadores de disposições extremamente variadas, de natureza diversa, geralmente muito heterogêneas e, às vezes, contraditórias. (MONTEIRO; FERREIRA, 2012, p. 155, grifo do autor).

A perspectiva de Lahire, de uma sociologia em escala individual, concebe o indivíduo como produto de múltiplos fenômenos que ocorrem em sua vida. Esse ponto de vista é de um social individualizado, de uma realidade social em 
sua forma incorporada, interiorizada (LAHIRE, 2005). Por isso,

[...] os atores são o que as suas múltiplas experiências sociais fazem deles. São chamados a ter comportamentos, atitudes variadas segundo os contextos em que são levados a evoluir. Longe de ser a unidade mais elementar da sociologia, o ator é sem dúvida a realidade social mais complexa a apreender. (LAHIRE, 2002, p. 198).

Trabalhar com as trajetórias de vida apresenta-se como uma possibilidade de fazer da individualidade um elemento que contribui para a elaboração de uma metodologia que tem no sujeito, enquanto ser histórico, um elemento central na busca de compreender a realidade social (BRAGANÇA, 2012).

As marcas da memória encerram uma ambiguidade latente, são indeléveis e opacas, uma névoa espessa mascara os traços de suas pegadas. As recordações não são nunca límpidas, cristalinas, elas repousam no fundo de uma tela recoberta por camadas superpostas de tinta. [...] A trilha de seu passado somente é revelada através de uma cuidadosa recuperação arqueológica. (ORTIZ, 2010, p. 7).

Para a análise das trajetórias dos sujeitos da EJA, realizamos a interlocução com as ideias de Bourdieu e Lahire, nos termos do pensamento de Bonaldi (2013), quando argumenta a favor de uma articulação teórica complementar entre esses autores. 0 primeiro autor, contribuindo com a formação de um quadro teórico mais amplo a partir de sujeitos com posições sociais homólogas; o segundo, dando contribuição à inteligibilidade das trajetórias individuais face aos destinos coletivos. Portanto, situado nessas duas vertentes teóricas, reconhecendo suas diferenças, optamos por uma ênfase interpretativa do material empírico das entrevistas a partir de uma perspectiva exploratória e heurística, aberta a novas problematizações.

\section{Metodologia de pesquisa}

A abordagem metodológica utilizada foi a qualitativa, por ressaltar as particularidades do fenômeno e por se voltar mais ao processo do que à estrutura social especificamente (SILVA, 2001). Como instrumento de coleta de dados, foi utilizada a entrevista semiestruturada por permitir recolher informações sobre determinado tema e por consentir que sejam incorporados temas que venham a surgir no decorrer das entrevistas (ROCHA; DAHER; SANT'ANNA, 2004). A pesquisa teve caráter exploratório e descritivo (TRIVIÑOS, 2011), tendo como categoria mediadora a questão do capital cultural e a posição social dos sujeitos no curso das suas trajetórias e imposições estruturais nas condições de vida.

O grupo de entrevistados se constituiu de sujeitos oriundos de um universo de concluintes do $3^{\circ}$ segmento da EJA/EaD do CESAS. Dois desses sujeitos foram buscados a partir de seu perfil na rede social Facebook, em razão de termos encontrado dificuldades na liberação dos dados pessoais dos ex-alunos com a instituição de ensino. Os outros dois entrevistados foram contatados via indicação de professores da escola. Tivemos, através do sítio do CESAS, o blog "Educação de jovens e adultos a Distância: desafios do aprender" (BLOGSPOT, 2017), acesso aos nomes dos egressos da primeira turma. Dos 120 pioneiros, 29 possuem perfil na rede social Facebook. Encaminhamos a correspondência solicitando adesão à nossa pesquisa para dezessete deles e tivemos a adesão de apenas duas pessoas. Aguardamos o aceite de outros possíveis interessados, mas como não tivemos mais adesões, pedimos ajuda aos professores, que nos indicaram mais alguns nomes, em torno de dez pessoas. Desses, apenas dois egressos se prontificaram em contribuir com o nosso trabalho.

\section{Os egressos, as suas narrativas e trajetórias}

No Quadro 1 abaixo, fazemos uma apresentação sintética dos quatro sujeitos entrevistados. 
Quadro 1 - Perfil dos sujeitos da pesquisa

\begin{tabular}{|c|c|c|c|c|}
\hline $\begin{array}{l}\text { ENTREVISTADO } \\
\text { E IDADE* }\end{array}$ & $\begin{array}{l}\text { OCUPAÇÃO DO } \\
\text { ESTUDANTE }\end{array}$ & $\begin{array}{l}\text { PAIS: OCUPAÇÃO E } \\
\text { ESCOLARIDADE }\end{array}$ & FAMÍLIA & $\begin{array}{l}\text { RETORNO À } \\
\text { ESCOLA }\end{array}$ \\
\hline Lucas: 55 anos & $\begin{array}{l}\text { Militar do } \\
\text { Exército }\end{array}$ & $\begin{array}{l}\text { Mãe: dona de casa } \\
\text { Pai: funcionário } \\
\text { público } \\
\text { Estudaram somente } \\
\text { até a } 4^{a} \text { série do } \\
\text { ensino primário }\end{array}$ & $\begin{array}{l}\text { Tem } 8 \text { irmãos, é } \\
\text { casado e tem um } \\
\text { filho e duas filhas } \\
\text { Todos os seus } \\
\text { irmãos concluíram a } \\
\text { faculdade }\end{array}$ & $\begin{array}{l}\text { Retorno aos } \\
\text { estudos depois } \\
\text { de } 28 \text { anos } \\
\text { parado }\end{array}$ \\
\hline Maria: 42 anos & $\begin{array}{l}\text { Secretária } \\
\text { Parlamentar }\end{array}$ & $\begin{array}{l}\text { Mãe: agricultora } \\
\text { familiar } \\
\text { Pai: agricultor } \\
\text { familiar } \\
\text { Estudaram somente } \\
\text { até a } 4^{a} \text { série do } \\
\text { ensino primário }\end{array}$ & $\begin{array}{l}\text { Tem } 3 \text { irmãos, é } \\
\text { casada e tem dois } \\
\text { filhos: um no ensino } \\
\text { fundamental e outro } \\
\text { na faculdade }\end{array}$ & $\begin{array}{l}\text { Retorno à } \\
\text { escola quase } \\
20 \text { anos } \\
\text { depois de ter } \\
\text { interrompido } \\
\text { os estudos }\end{array}$ \\
\hline Mateus: 46 anos & $\begin{array}{l}\text { Agente de } \\
\text { Portaria e } \\
\text { Pastor }\end{array}$ & $\begin{array}{l}\text { Mãe: professora } \\
\text { aposentada } \\
\text { Pai: autônomo } \\
\text { A mãe fez curso } \\
\text { Normal e o pai } \\
\text { tem a } 4^{a} \text { série do } \\
\text { primário }\end{array}$ & $\begin{array}{l}\text { Tem um irmão e } \\
\text { é casado }\end{array}$ & $\begin{array}{l}\text { Depois de mais } \\
\text { de } 20 \text { anos, } \\
\text { ele voltou a } \\
\text { estudar } \\
\text { Ingressou em } \\
\text { um curso de } \\
\text { Design Gráfico }\end{array}$ \\
\hline Pedro: 21 anos & $\begin{array}{l}\text { Assistente } \\
\text { Administrativo } \\
\text { em um } \\
\text { escritório de } \\
\text { advocacia }\end{array}$ & $\begin{array}{l}\text { Mãe: advogada } \\
\text { Pai: professor }\end{array}$ & $\begin{array}{l}\text { Tem quatro irmãos } \\
\text { e é solteiro. Dois } \\
\text { irmãos cursam a } \\
\text { faculdade, um já é } \\
\text { formado e o outro } \\
\text { está no ensino } \\
\text { fundamental }\end{array}$ & $\begin{array}{l}\text { Retorno aos } \\
\text { estudos depois } \\
\text { de dois anos } \\
\text { Ingressou } \\
\text { no Instituto } \\
\text { Federal de } \\
\text { Brasília e foi } \\
\text { aprovado em } \\
\text { um curso de } \\
\text { licenciatura na } \\
\text { UnB }\end{array}$ \\
\hline
\end{tabular}

Fonte: Elaborado pelos autores deste artigo.

* Nomes fictícios.

Iniciamos o relato das entrevistas com o estudante Lucas, tratando de aspectos da sua experiência escolar e eventuais dificuldades. 0 entrevistado teve oportunidade de vivenciar bons momentos na escola pública. Seu relato revela que desfrutou de acesso a professores que primavam pela aprendizagem de seus alunos. 
A gente lia muito, tinha que ler demais com ela. [...] Eles queriam fazer a gente raciocinar, então isso na forma que a gente aprendeu a estudar foi um diferencial, né? Tanto que, graças a Deus, assim, eu não sou muito de estudar não, mas todos os concursos que eu prestei eu passei. Será que eu sou mais inteligente? Não, não sou. Agora, eu fui muito bem preparado, graças a Deus. (LUCAS).

Apesar das dificuldades enfrentadas, o acesso a bons professores na primeira fase da escolarização lhe deixou como herança uma estrutura bem delineada, sobre a qual ele pode construir sua trajetória social, familiar e profissional e, mais tarde, voltar à escola e concluir seu processo de escolarização formal. Para Lahire (1997, p. 36),

[...] existe sempre, em cada ser social, em qualquer grau, competências, maneiras de ser, saber e habilidades, ou esboços de disposições, delineadas, porém não atualizadas em algum momento da ação, ou, de maneira mais ampla, em algum momento da vida, que podem ser postas em ação em outros momentos, em outras circunstâncias.

No relato de um dos egressos também foram identificadas questões de saúde que dificultaram o acesso e a permanência na escola. Deparou-se com impedimentos geográficos, estudante moradora da zona rural, distante da escola.

A gente tinha uma rotina que a gente tinha de trabalhar na roça; a gente estudava de manhã, tinha que caminhar três quilômetros, tinha que chegar em casa, ir trabalhar na roça. À noite, nos meus primeiros três anos, não tinha nem luz elétrica. A gente tinha uma lamparina. Eu fazia meu dever de noite. Depois de 9, 10 horas da noite. Dormia em cima do livro. (MARIA).

Maria experimentou aspectos que contribuíram para que não vivenciasse um processo de escolarização regular, fato que a levou a buscar, muito mais tarde, uma oportunidade de educação adequada à sua defasagem. Como bem frisa Bourdieu (2011), a desigualdade na aquisição de capital cultural apresenta-se como uma perspectiva para a compreensão da diferença de desempenho escolar dos sujeitos e para a ruptura com a visão que considera o sucesso ou fracasso escolar como efeito de aptidões e dons. "Aí, depois que eu fiquei sem estudar [...] fiquei um tempão sem estudar, uns quatro anos. Porque eu fiquei muito doente. Perdi o primeiro ano e depois eu disse: 'eu não vou estudar assim mais."” (MARIA).

A situação econômica da família lhe impôs a necessidade de trabalhar desde cedo, o que contribuiu para uma situação educacional repleta de dificuldades e limitações, retardando seu processo de escolarização. Maria se depara com muitas dificuldades em prosseguir com os estudos e superar a condição de pobreza que vivenciava junto à sua família. Então, opta por ir à busca de melhores condições de vida. Ao mudar de cidade, deixando sua família, é que ela pôde retomar os estudos e então concluir o processo de escolarização, se qualificar e adquirir certo capital cultural, sob a forma de certificados escolares.

Identificou-se também no estudo que o envolvimento e o uso de drogas, ligado a um estilo de vida mais hedonista, pode afastar as pessoas do ambiente escolar. "Essa época da minha vida em que eu larguei os estudos, em 1986,1987 , eu tinha 16,17 anos, e eu comecei a beber, comecei a usar drogas, comecei a me envolver com essas coisas; e esse foi um dos motivos que fez com que eu abandonasse os estudos." (MATEUS).

Desse modo,

[...] se poderia dizer aqui que o sucesso reside, para uma parte dos estudantes, em sua capacidade de inibir disposições sociais inadequadas (com relação ao objetivo desses estudantes terem êxito). Observa-se, então, uma verdadeira luta, às vezes muito consciente, dos estudantes contra uma parte deles mesmos, que eles fazem de tudo para manter no sono. (LAHIRE, 2002, p. 67).

Mateus reconhece o seu envolvimento com o consumo de álcool e outras drogas como um elemento que contribuiu para o abandono da escola. Assim, 
Lá atrás, os problemas que eu enfrentei foi a escolha que eu fiz de abandonar os estudos. Eu fui influenciado e me deixei levar, e me envolvi com coisas que só trouxe prejuízo pra minha vida. Coisa que prejudicou muito a minha vida. Atrasou muito, perdi muito tempo na vida por causa dessas escolhas erradas lá atrás. Eu não conseguia enxergar as coisas. (MATEUS).

Para crianças e adolescentes em situação de risco, a escola poderia ser um ambiente protetor. Um ambiente que oferece acolhimento, formação e preparo para lidar melhor com circunstâncias que expõem ao risco, haja vista que

[...] em um mesmo sujeito coexistem disposições ascéticas e disposições hedonistas, pois um mesmo indivíduo desempenha papéis variados. 0 sujeito nunca é apenas um estudante. Ele traz para escola, junto com a identidade de estudante, outras experiências de socialização que interferem de forma mais ou menos favorável em seu processo. (ARAÚJO, 2015, p. 44-45).

Apesar de serem muitas as nuances que envolvem a evasão escolar, normalmente um ambiente familiar de pouco estímulo aos estudos favorece esta situação. Não foi detectada, nas entrevistas, falta de incentivo por parte dos pais para que os filhos estudassem, mas identificou-se que, diante de uma certa instabilidade financeira, a ênfase recaiu sobre a importância do trabalho e não dos estudos.

Meu 'velho', teve uma certa época que ficou ruim de dinheiro. Então a gente tinha que ajudar a cuidar dos mais novos. Então eu tive que trabalhar. (LUCAS).

A gente tinha que sobreviver. Então não tinha como estudar. (MARIA).

Os entrevistados são pessoas que se depararam com condições adversas de vida e tomaram as decisões que lhes foram possíveis naquele momento, diante daquela realidade que se estabelecia.

Existem casos que as rupturas são tão numerosas, e as condições de vida familiar, econômica... tão difíceis que, ou o tempo que os pais podem dedicar aos filhos é absolutamente limitado, ou suas disposições sociais e as condições familiares estão a mil léguas das disposições e das condições necessárias para ajudar as crianças a 'ter êxito' na escola. (LAHIRE, 1997, p. 335, grifo do autor).

Deduz-se de alguns relatos, a necessidade de apoio, a relevância de alguém para ajudar a enxergar um caminho e a persistir. A necessidade de alguém que impulsione, que ampare e coopere com a caminhada. Assim, "a influência na escolarização das crianças, da 'transmissão dos sentimentos' é importante, uma vez que sabemos que as relações sociais, pelas múltiplas injunções preditivas que engendram, são produtoras de efeitos de crenças individuais bem reais" (LAHIRE, 1997, p. 172-173, grifo do autor).

Os entrevistados são sujeitos das classes populares e média; seus pais, com duas únicas exceções, são analfabetos funcionais, estudaram apenas até a quarta série e, por imposição de situações adversas, enfatizaram o trabalho, condição de sobrevivência, em detrimento dos estudos.

Uma condição familiar mais permissiva, que não fornece suporte socioafetivo aos seus membros, acaba por se configurar em uma postura menos comprometida, que não se coaduna com as exigências e comportamento mais condizentes com a regularidade da escola.

Eu nunca tive muito acompanhamento dos meus pais não, na questão de escola. Sempre foi mais assim, mais da minha conta mesmo. Eles acompanhavam mais quando eu tinha algum problema na escola, e fazia alguma coisa assim, mas questão de estudo mesmo sempre foi assim, por conta própria mesmo. (PEDRO).

Não tem outro jeito na vida; se a pessoa não estudar, ela não tem como ter uma boa colocação no mercado de trabalho. (MATEUS).

Dado da pesquisa revelou uma nova geração de alunos da EJA: o jovem que vem procurando essa modalidade de ensino para concluir rapidamente os estudos. Para Pedro a EJA representou uma oportunidade de recuperar o tempo perdido. Segundo Haddad e Di Pierro (2000), a partir da década de 1980, os programas de EJA passaram a receber um novo grupo social, 
jovens de origem urbana, cujo percurso escolar foi malsucedido.

Apoiado nos casos estudados, percebe-se aspectos importantes sobre o abandono dos estudos e a decisão de voltar à escola e concluir o processo de escolarização. Lucas e Maria viveram as dificuldades enfrentadas pela família, e isso os obrigou a rever as condições de estudo, trocando o turno diurno pelo noturno e, mais tarde, abandonando a escola. Maria enfrentou dificuldades com a doença, também conviveu com a falta de estímulos por parte dos professores e com a discriminação pelo fato de ter origem rural e vir de uma família pobre. Esses aspectos contribuíram para a constituição de uma trajetória de vida marcada por constrangimentos que influenciaram em seu processo escolar.

Pedro e Mateus, se não sofreram as dificuldades de uma família com poucos recursos, viram-se envolvidos em situações sociais que os afastaram dos estudos.

Para Lahire (1997), a orientação social da ação individual e a forma como os indivíduos lidam com as múltiplas influências sociais se dão por interação com espaços sociais heterogêneos, cedendo ou opondo-se às situações experimentadas e assim tomando suas decisões. De acordo com Nogueira (2004), no processo de socialização e na incorporação de disposições, a realidade social não é tão somente algo exterior ao indivíduo, mas configura-se na sua própria subjetividade e se revela nas suas motivações para pensar, avaliar e agir. Castel (2005), ao tratar de uma certa "rigidez bourdieusiana" em relação ao fato de que a vida social é feita de exigências impiedosas, que podem romper os sujeitos sociais, sufocar projetos, privando-os das condições para a sua realização, frisa que na obra de Bourdieu se demonstra a recusa em aceitar que existem apenas reprodução e destino nas trajetórias sociais - embora haja muita reprodução social e muitas vezes as trajetórias sociais assumam a característica de destino -, e que a margem de manobra do sujeito só entra em ação a partir da consciência das coerções existentes no mundo social. Gartman (2007) nos dá certa pista para compreender teoricamente, em conexão com o nosso estudo sobre as trajetórias dos egressos da EJA/EaD, que Bourdieu trabalha com a concepção de que o habitus é resultado da mediação entre as estruturas e as estratégias de ação, motivando diferentes ações em diferentes circunstâncias, tendo resultados imprevisíveis e operando por lógica prática e intuitiva. Comenta ainda Gartman (2007) que o habitus, no pensamento de Bourdieu, pode operar com lapsos de tempo, vindo a colidir com estruturas sociais alteradas. É o que se denomina hysteresis. Bourdieu (2001) frisa a existência de habitus clivados, destroçados, ostentando a marca das condições de formação contraditórias de que são o produto.

Nossos entrevistados se depararam com as mesmas imposições: concluírem a educação formal para melhor se posicionarem no mercado de trabalho. Os sujeitos vivenciaram um adiamento daquilo que poderia ter sido feito em um momento mais apropriado e mais confortável e, assim, se confrontaram com a necessidade de compensar esse tempo. As pessoas parecem não ter muita consciência do percurso que vão seguindo, sendo provocadas a partir de constrangimentos estruturais. É como se as situações se apresentassem como um cenário que vai se descortinando e as decisões e posturas vão sendo assumidas e adequadas à medida que essa trama vai se desenrolando e cujo final desconhecem. Os sujeitos egressos da EJA/EaD operaram em um contexto de exigências em relação ao posicionamento na estrutura social, por exemplo, no âmbito econômico e a ação social guiada por sentido prático no que toca à valorização da educação escolar na modalidade EaD.

Lucas viveu dificuldades que o levaram a abandonar os estudos para trabalhar e ajudar financeiramente sua família. Ao mesmo tempo em que essa situação lhe mostrou a dureza da realidade da vida, lhe fez amadurecer. Ele cita como referência positiva em sua trajetória um 
tio, irmão de sua mãe, que saiu de casa cedo, se tornou economiário e conseguiu progredir dentro da Caixa Econômica Federal, onde ocupou bons cargos. Este tio foi mais um exemplo de pessoa bem-sucedida que lhe serviu de referencial. A dificuldade de estudar à noite, depois de um dia de trabalho, exige dele a necessidade de se esforçar e de gerir melhor o seu tempo. Ele cria métodos de estudo, ele aprende a estudar. "Então eu comecei a perceber que o tempo começou a ficar pequeno para mim, né. Então, eu comecei a ter métodos de estudar." (LUCAS).

As situações adversas vivenciadas por Maria não lhe aprisionaram, pelo contrário, lhe inspiraram e estimularam a buscar a superação. Sua angústia quanto ao futuro, sua vontade de viver bem e com saúde, o desejo de dar uma condição de vida melhor à sua mãe e a seus irmãos são aspectos que lhe incutiram força e vontade para o enfrentamento e a superação da realidade social em que nasceu. "Eu não desisti. Mesmo com as dificuldades, mesmo com tudo. Mesmo com todas as dificuldades que eu tive, eu nunca quis desistir." (MARIA).

Mateus não se lembra de ter visto o pai estudando algum dia, mas fala com orgulho da mãe, que até hoje lhe estimula a estudar. A mãe que se formou adulta e se tornou professora é o seu exemplo. "A minha mãe foi um exemplo pra mim porque ela se formou depois de velha, com mais idade. Ela fez curso normal e se formou, é professora." (MATEUS).

Para Lucas, os estudos e a escolarização se deram em razão de sua vida profissional, que exigia o Ensino Médio para a progressão da carreira. Isso o estimulou a voltar a estudar e concluir os estudos.

Mateus foi impulsionado pela necessidade de crescer profissionalmente, em busca de melhores condições de vida para si e para sua família. Foi principalmente por essa razão que se deu o seu retorno à escola. Contudo, também se identificou que a conclusão dos estudos lhe investiu de algo mais que um mero saber fazer, uma competência técnica. Os estudos lhe devolveram a autoconfiança e a autoestima. Assim,
[...] a presença de jovens alunos na EJA deveria ser expressão de que a escola é parte efetiva de seus projetos de vida. E de que eles e elas estão exercendo seus direitos à educação básica republicana e de qualidade e não apenas participando de um mero jogo funcional de correção de fluxo escolar ofertado em instituições de espaços e tempos deteriorados. (CARRANO, 2007, p. 9).

É certo que o trabalho, a preocupação com a sobrevivência, com a família, ao mesmo tempo em que rivalizam com os estudos, também servem de estímulo à perseverança do estudante, pois muitas vezes são essas mesmas condições que impulsionam e determinam o retorno aos estudos.

São muitos os motivos que impediram parte da população de frequentar a escola: a necessidade de trabalhar e ajudar nas despesas da família; os trabalhos domésticos; problemas de aprendizagem; desinteresse pelos estudos e pela escola; distância da escola. Além das dificuldades do próprio sujeito, há também os impedimentos externos, a falta de escola e de políticas públicas que atendam aos interesses e necessidades educacionais desses sujeitos. A procura pela EJA é consequência de um processo de impedimento de frequentar a escola regular, o que vem sendo justificado pelo mal explicado fracasso escolar. Portanto,

[...] urge ver mais do que alunos ou ex-alunos em trajetórias escolares. Vê-los jovens-adultos em suas trajetórias humanas. Superar a dificuldade de reconhecer que, além de alunos ou jovens evadidos ou excluídos da escola, antes do que portadores de trajetórias escolares truncadas, eles e elas carregam trajetórias perversas de exclusão social, vivenciam trajetórias de negação dos direitos mais básicos à vida, ao afeto, à alimentação, à moradia, ao trabalho e à sobrevivência. (ARROYO, 2007, p. 24).

Lucas, por exemplo, ressalta por que parou de estudar: "Eu era muito ligado à profissão. Eu não tinha horário. Nós não tínhamos aí, no início dos anos 80, nenhuma coisa a distância. [...] a dificuldade minha era essa, do meu expediente." 
A EJA também tem sido uma opção para muitos jovens que, como Mateus, têm que conciliar trabalho e estudo. 0 ensino médio na modalidade a distância permitiu a Maria administrar seu tempo. Ela conseguiu estudar e ainda cuidar da família: "ser pai, ser mãe, ser esposa e tudo isso" (MARIA). Já Pedro afirma que optou pela EJA/EaD porque dessa forma não teria que comparecer à escola todos os dias. Essa afirmação também nos permite pensar que os programas de EJA, além de possibilitar a democratização das oportunidades de formação a jovens e adultos trabalhadores, vem perdendo essa especificidade e passando a desempenhar funções de aceleração de estudos de jovens com defasagem idade-série e a regularização do fluxo escolar (HADDAD; DI PIERRO, 2000).

[...] as estratégias de oferta de EJA por meio da Educação a Distância com uso de tecnologias de apoio à aprendizagem são realidade no mundo atual, porém ainda têm uso acanhado no Brasil. Efetivamente, a oferta de EJA de forma semipresencial, híbrida ou a distância pode favorecer a atratividade dos cursos para os estudantes trabalhadores que, muitas vezes, não dispõem de tempo para cursar um programa de forma presencial com horários rígidos. (BRASIL, 2016, p. 113).

A entrevista de Lucas desvela o mecanismo da flexibilidade da EAD, ao dizer da sua experiência nessa modalidade de ensino que exige uma "disciplina de soldado". "Só tem sucesso quem tiver disciplina. Indisciplinado, esqueça, não faz curso a distância! Esse foi o grande ensinamento que eu tive no ensino a distância." (LUCAS).

Ainda como fala complementar à de Lucas, Maria diz que o seu desafio foi administrar o próprio tempo. Conseguir estudar, aprender e concluir, se organizar.

Meu objetivo era terminar. Tinha que estudar, tinha que trabalhar, tinha que escolher caminhos. [...] eu estudava às vezes depois de deixar minhas crianças para dormir, quando não dava tempo para estudar aqui [no trabalho]. Era no ônibus, onde dava. Eu administrava meu tempo e conseguia estudar. (MARIA).
Quando indagado sobre como a sociedade enxerga as pessoas que concluíram os estudos através da EJA, Lucas afirma que ainda existe certo estigma com relação a este aluno, ainda há preconceito: "De onde você é? Onde você estudou? Às vezes o camarada não vê o profissional, ele vê onde o camarada concluiu os estudos. Nós somos preconceituosos."

De acordo com Maria, a pessoa escolarizada pela EJA ainda é vista com discriminação. Um aspecto que reforça uma autoestima negativa e que estigmatiza os sujeitos dessa modalidade de ensino: "Eles falam assim: 'Por que você não estudou quando era novo? Era vagabundo quando era novo?' Eles ainda têm muito essa ideia."

Muitas pessoas acreditam que a EJA é uma educação fraca, "não tão boa". Maria afirma sentir essa discriminação. Entretanto não se deixa abater, reage com mais vontade de estudar. Ela afirma que o fato de ser um curso a distância foi indiferente, ainda que tenha facilitado a conclusão do ensino médio; se fosse presencial, teria que aguardar um pouco mais para poder concretizar seu objetivo, que era concluir para fazer uma faculdade. Já Mateus afirma que não vê discriminação em relação ao jovem e adulto escolarizado pela EJA. Ele acredita que uma pessoa mais velha, que não estudou por um motivo ou outro, e que volta a estudar e conclui os estudos, é bem vista pela sociedade e pela família.

0 retorno aos estudos me trouxe melhoria profissional, porque eu consegui um outro emprego [...] que tá me dando condição de pagar os meus estudos, então isso aí já foi um benefício. 0 fato de ter concluído me ajudou de duas formas: profissionalmente e a ingressar na faculdade. (MATEUS).

Por sua vez, Pedro diz que é indiferente, para efeitos de conclusão dos seus estudos, o fato do curso ser à distância ou presencial, pois pensa que o concluir depende mais do esforço e do empenho de cada um. Contudo não deixa de reconhecer que o fato de ser um curso a distância o ajudou, porque o deixou livre para estudar na hora que quisesse. 
A escolha pela EJA/EaD possibilitou conciliar trabalho e educação, pela forma flexível com que engendra o tempo e a distância. Os entrevistados, ao optarem pela EJA/EaD, precisaram buscar novas competências, tiveram que aprender informática, que desenvolver habilidades indispensáveis ao aluno da EaD: disciplina, autodidatismo, gestão do tempo e métodos de estudo. "'Cara', tem que ter uma disciplina de soldado para fazer. Só tem sucesso quem tiver disciplina. Indisciplinado, esqueça, não faz curso a distância." (LUCAS).

Mesmo com o reconhecimento legal da EJA/ EaD e a importância que essas duas modalidades de ensino alcançaram, ainda são vistas com certa suspeita, mesmo entre os profissionais da educação. Todavia, percebe-se que a junção dessas duas modalidades de ensino vem contribuindo para atenuar as desigualdades quanto ao acesso e, ainda, com o desafio da permanência no sistema de ensino, dando oportunidade de ingresso ou retorno à educação.

A busca pela escolaridade demonstra que os sujeitos estão cientes da complexidade dos valores que regem a sociedade em que vivem. Se, por um lado, a escolaridade não garante, por si só, a inserção no mercado de trabalho, por outro, sua falta impõe circunstâncias mais intensas de exclusão, porque lhes veda o acesso a melhores possibilidades de trabalho e de condições de vida. Os entrevistados buscaram os motivos para o retorno e a conclusão dos estudos. Não só a dimensão do mercado de trabalho foi o elemento instigante. "A fé, a vontade de conquistar coisas diferentes. Isso é meu." (MARIA).

A escola e a conclusão do Ensino Médio deram uma expectativa de melhoria para a vida social e profissional dos entrevistados. Eles reconhecem o valor da escola: "A escola sempre foi uma coisa boa na minha vida. Eu é que fui burro de não enxergar isso." (MATEUS).

A aquisição de capital cultural não foi o determinante no retorno ao processo de escolarização desses egressos. Percebe-se que foram as possibilidades de melhores condições de trabalho e renda que os influenciaram a retornar à sala de aula.

0 fator econômico teve um peso decisivo em relação ao abandono da escola e ao posterior retorno. Este estudo identificou que a necessidade de trabalhar e ajudar nas despesas da família é o motivo mais frequente para a interrupção dos estudos. Todavia, também foram identificados o desinteresse pela escola, o envolvimento com drogas e questões de doença. Não se pode deixar de mencionar que a falta de escola e de políticas públicas voltadas para esse público contribuem para o distanciamento desses sujeitos da escola. Ficou claro que, diante de dificuldades financeiras, a ênfase recaiu sobre a prioridade do trabalho e não dos estudos. Mesmo porque o trabalho é o responsável pelo sustento das famílias.

Os egressos participantes desta pesquisa, com exceção de Pedro, são oriundos de um ambiente familiar com pouco capital cultural, tendo as dificuldades financeiras levado ao abandono dos estudos. Esse é um dos motivos pelos quais os filhos das classes populares são mais suscetíveis à evasão. Embora ambicionada e tida em alto conceito, a educação ainda é, entre as classes populares, algo de difícil acesso, um bem caro, que requer tempo de investimento, nem sempre disponível, pois a necessidade de trabalhar se impõe desde cedo.

Apesar de todas as dificuldades vivenciadas pelos entrevistados, a conclusão do Ensino Médio interferiu positivamente no destino social e profissional desses egressos. 0 que os motivou a voltar a estudar foi a busca por melhores condições de vida. Também se observa, além do sonho de concluir os estudos, a vontade de entrar para uma universidade e assim garantir a posse de um capital cultural institucionalizado, o que lhes garantiria melhores condições de competir no mercado de trabalho.

Lucas buscou uma oportunidade de dar prosseguimento à sua formação. Depois de concluído o Ensino Médio, ele continuou a estudar. Aquele garoto que teve que abandonar os estudos para ajudar a sustentar a família, 
cresceu e se tornou Capitão do Exército. Ele está em vias de se aposentar, mas já traçou mais uma meta: fazer o terceiro grau. Para Lucas, se houvesse a oferta de EaD há mais tempo, ele teria voltado aos estudos formais bem mais cedo. Ele não só concluiu o Ensino Médio como também prosseguiu fazendo outros cursos de formação à distância.

Eu não parei mais [risos]. Fiz até um curso de gestão na Fundação Getúlio Vargas a distância. Eu aprendi a estudar. [...] fiz uns 5 cursos só na Enap. ${ }^{7}$ A minha ideia agora, eu já tô quase aposentando, é fazer o terceiro grau, na UNISUL, porque ela tem um convênio com o exército. (LUCAS).

Maria internalizou a imagem da mãe e da avó, mulheres trabalhadoras da roça. Em seu relato há a percepção da força, da determinação e do empenho dessas duas mulheres de sua família, o que se configurou como um modelo de superação. Maria, hoje secretária parlamentar, administra tudo o que envolve a vida profissional do parlamentar e o gabinete. Segundo ela, o retorno à escola e a conclusão do Ensino Médio trouxe oportunidades. Trouxe uma melhoria em sua autoestima, lhe possibilitou um autoconceito positivo e, consequentemente, um trânsito mais confiante pela vida profissional e social. "Foi muito importante porque no momento que eu terminei eu pude dizer assim: 'não, agora eu concluí e agora eu posso galgar, posso conseguir promoções aqui mesmo, dentro do trabalho."' (MARIA).

Maria tomou gosto pela EaD e fez outros cursos. Estudou Gestão Pública na faculdade, se pós-graduou em Gestão de Cidades - os dois cursos a distância. E agora faz Ciências Contábeis, também a distância.

Mateus, após concluir o Ensino Médio por meio da EJA a distância, obteve outra conquista: é com orgulho que ele anuncia que vai ingressar no ensino superior. Para ele, independe de a EJA/EaD não ser bem vista ou de a faculdade

7 A Escola Nacional de Administração Pública (Enap) é uma escola de governo, do Poder Executivo Federal, que oferece formação e aperfeiçoamento em Administração Pública a servidores públicos. onde vai estudar é a mais bem avaliada pelo MEC, o que importa é ter conseguido, com tão pouca ajuda, diante de tantas dificuldades. Ter tido a força e o empenho de retomar, de recomeçar, concluir e prosseguir, pois já entendeu que a educação é um processo, por isso continuada. Concluir o Ensino Médio deu a Mateus a oportunidade de ingressar em um curso superior e obter um emprego que lhe dá condições de pagar os seus estudos. Além disso, lhe trouxe expectativas de melhoria de vida, de uma remuneração melhor, uma autoestima positiva. Mateus, que já se habituara a conciliar trabalho e estudo, empolgado com as possibilidades de se escolarizar ainda mais e crescer na vida, não desanima. Ele prestou o vestibular para o curso de Design Gráfico, foi aprovado e está comprometido com esse novo desafio, com a perspectiva de se aperfeiçoar e crescer ainda mais.

Pedro está construindo seu percurso, buscando a qualificação de seu processo educacional; e ele conseguiu, está matriculado na Universidade de Brasília. Pelo muito que possui, como os conteúdos cognitivos e o acesso ao capital cultural e social que os pais lhe oportunizaram, não teve dificuldades.

0 retorno aos estudos deu aos entrevistados um sentimento positivo de autovalorização. Retomar os estudos lhes deu mais que qualificação para o trabalho, devolveu-lhes a autoestima, o autoconceito positivo.

\section{Conclusão}

Dentre aqueles que buscam a EJA, muitos nunca frequentaram a escola. Outros começaram a estudar, foram obrigados a interromper os estudos por motivos variados, mas quase sempre enfrentaram condições adversas de vida. Eles escrevem um pouco, sabem ler, mas nem sempre compreendem o que leem. Entretanto, trazem consigo conhecimentos adquiridos ao longo da vida, o que muitas vezes contribui para o retorno e conclusão dos estudos. 
A escola e a escolarização têm significados diferentes para cada um. Nesta pesquisa percebeu-se que, na concepção dos entrevistados, a educação contribui para a atenuação das desigualdades sociais, ao propiciar qualificação para o mercado de trabalho. A procura pela escola veio da consciência de que a não escolarização inflige situações de exclusão ao impedir o acesso a melhores oportunidades de trabalho. 0 acesso à escolarização ainda não está garantido a todos. Ainda persiste certa inacessibilidade para os que mais necessitam e essa persistência reforça as desigualdades. A oferta de EJA/EaD pode contribuir para reparar esta situação. A educação é uma conquista, porém ela continua reproduzindo a mesma organização social. Ainda não se conseguiu socializar os benefícios da escolarização, e "ser analfabeto ou estar excluído de uma escolaridade básica traz uma série de privações concretas e simbólicas, que se manifestam desde as exigências do mercado de trabalho até as práticas sociais presentes em nosso cotidiano" (ANDRADE, 2004, p. 104).

Os sujeitos desta pesquisa, a partir de suas vivências e das particularidades de suas trajetórias, foram se conscientizando da necessidade de romper com certos determinantes sociais. As dificuldades da vida e a vontade de superação os mobilizaram ao retorno e à conclusão dos estudos, e isso lhes deu autoestima, autoconfiança e perspectiva para poderem melhorar suas vidas.

Os sujeitos da EJA constituem um grupo social que, em uma perspectiva bourdieusiana, vivenciaram o processo de exclusão devido à reprodução social e escolar, sofrendo constrangimentos estruturais. Isso os colocou em desvantagem no processo de escolarização. Há elementos que apontam para a clara relação entre a desigualdade entre as classes sociais e as desigualdades escolares. 0 caso de Maria exemplifica bem os constrangimentos estruturais que sofreu na escola tanto por causa da sua origem rural, quanto por ser de uma família pobre. A dura rotina de trabalho na roça, a caminhada de três quilômetros até a escola e o estudo à base da lamparina desvelam o fato de que o desempenho escolar dos sujeitos não pode considerar o fracasso ou o sucesso escolar como mero efeito de aptidões ou dons. Em suma, o sistema educacional não funciona isoladamente das condições materiais de existência dos sujeitos, sendo que outras estruturas operam, concomitantemente, para perpetuar a desigualdade.

Bourdieu (2002, p. 14-15), ao discutir os aspectos que perpetuam e legitimam a desigualdade de acesso à educação, reproduzindo e convertendo a desigualdade social em desigualdade educacional, enfatiza que o sistema não é esse que "conserva, reproduz; digo contribui para conservar. 0 sistema de ensino é um dos mecanismos pelos quais as estruturas sociais são perpetuadas. Existem outros: o sistema sucessório, o sistema econômico, a lógica da velha fórmula marxista segundo a qual o 'capital vai ao capital'".

Do ponto de vista subjetivo, é importante salientar a referência positiva e certa internalização - efeito de hysteresis - dos modelos impulsionadores de superação intrafamiliares presentes nas trajetórias dos sujeitos, representados na figura das mães, avó e tio - símbolos da força, determinação e empenho, exemplificados no trabalho árduo -, em uma formação escolar "depois de velha" e na progressão na carreira profissional (casos de Maria, Lucas e Mateus). Dois dos quatro entrevistados têm irmão que concluiu ou está concluindo a faculdade, mas não há referência ao irmão como modelo impulsionador.

Três dos quatro sujeitos pesquisados são oriundos de um ambiente familiar pobre em capital cultural institucionalizado, mas não se pode creditar a esse fato a maior dificuldade na trajetória social vivida. As questões financeiras, de provisão das necessidades básicas da existência, são as que mais aparecem nos relatos e foram as que contribuíram para o abandono dos estudos em razão do trabalho. Um dos egressos se perdeu em vivências hedonistas 
e mais tarde acabou tendo que reconhecer a dinâmica impositiva da realidade social, admitindo a necessidade de compensar o tempo que foi subtraído à educação. Pedro teve uma condição diferenciada em relação aos demais egressos. Pedro vem de uma família de classe média. Os pais estudaram e lhe asseguraram as condições materiais para frequentar a escola. A questão financeira, que marca predominantemente o aluno da EJA, não teve implicação em sua trajetória escolar.

Pedro, entre os egressos da EJA/EaD, que retornou aos estudos depois de dois anos de interrupção, é o que tem a menor idade, 21 anos, enquanto os demais estão acima dos 40 anos e retornaram à escola depois de 20 anos. Depreende-se do perfil de Pedro uma nova imagem social do público da EJA - jovens, oriundos da classe média, pais com nível superior -, bem diferenciado daquela imagem ainda existente, de trabalhadores da cidade e do campo com baixa remuneração, com idade elevada, com pais com pouca ou nenhuma escolarização, participantes de cursos noturnos de alfabetização. As taxas de reprovação nos anos finais do ensino fundamental, gerando uma defasagem na relação idade-série, talvez seja uma das variáveis explicativas do fenômeno da juvenilização da EJA, tendendo a um crescimento de matrículas em cursos a distância. 0 que demanda investigações futuras.

A escolha pela EJA/EaD possibilitou aos sujeitos da pesquisa conciliar trabalho e educação, pela forma flexível com que a modalidade permite lidar com o tempo e a distância. Os entrevistados, ao optarem pela EJA/EaD, precisaram buscar novas competências, tiveram que aprender informática, a ter disciplina, a fazer a gestão do tempo e desenvolver métodos de estudo. Todos os sujeitos entrevistados ressaltaram a disciplina para o estudo a distância como um fator a ser aprendido e exercitado, configurado em uma rotina para a realização das atividades. A ideia da flexibilidade EJA/ EaD desloca, muitas vezes, o sentido da democratização do direito a ter direitos à educação escolar e às aprendizagens, e se apresenta falsamente para o público com a ideia ilusória de apenas "ganhar tempo", como se não exigisse do estudante o desenvolvimento de habilidades de autoaprendizagem, de autonomia na organização dos estudos e, em certos modelos pedagógicos de curso, a participação em processos de mediação com docentes e colegas. Em outra vertente, é importante ter a visão crítica de certos cursos EaD que preconizam o "ganhar tempo" com aceleração na certificação. Tais cursos podem assumir características massivas enquanto preocupação numérica em apenas ganhar em escala, como numa formação industrial, retirando maior grau de intersubjetividade entre os sujeitos pela simples automatização dos processos educativos e pedagógicos, enxugando ou esvaziando temas e questões sociais cotidianas como objetos da aprendizagem em relação às leituras de mundo de forma compartilhada (SOUSA, 2014). Esse autor ressalta que a questão não está no aspecto massivo em termos de cobertura e alcance social de um curso a distância, mas na intencionalidade que calibra a qualidade do processo de formação e a perspectiva de interação (SOUSA, 2014).

0 trabalho aparece nesta pesquisa como o elemento que influencia o retorno e a continuidade dos estudos. Esse regresso deu aos entrevistados um sentimento de valoração. Para os egressos da EJA/EaD, os benefícios da educação estão associados à melhor condição de inserção no mercado de trabalho. As escolhas são influenciadas pelas experiências vividas e pela posição que os sujeitos ocupam nas estruturas sociais (família, economia, profissão). Contudo, muitas vezes, os sujeitos deixam de fazer escolhas de acordo com o que se esperava de alguém que ocupa determinado lugar social.

Podemos comparar o sujeito destituído de capital cultural, econômico e social a Sísifo, ${ }^{8}$

8 Personagem da mitologia grega que, ao despertar a ira em Zeus, foi condenado a "'[...] rolar uma enorme pedra até $\mathrm{o}$ alto de um morro, mas quando já se encontrava bem avançado na encosta, a pedra, impelida por uma força 
condenado a rolar morro acima a insuportável carga de imposições que a sociedade de mercado lhe impõe e, diante das dificuldades de chegar ao topo, se vê enredado na teia dos diplomas e certificados, que acredita poderem franquear sua ascensão.

Entretanto o próprio sistema se incumbe de desvalorizá-los, de lhes tirar o lastro, ao elevaram continuamente as exigências escolares para ingresso e ascensão no mercado de trabalho. Exige-se, cada vez mais, outra formação, outro diploma, mais capital cultural. "Os detentores de capital não podem manter sua posição na estrutura social senão ao preço de reconversões das espécies de capital que detêm em outras espécies mais rentáveis e ou mais legitimas no estado considerado dos instrumentos de reprodução." (BOURDIEU, 2011, p. 10).

Ficam então perseguindo com perseverança o horizonte, mas quanto mais dele se aproximam, mais dele se distanciam. Segundo Bourdieu (2011), a escola, ao transparecer ser essa terra prometida, semelhante ao horizonte, que recua na medida em que se avança em sua direção, relega tal parcela da população a uma eliminação ainda mais estigmatizante. Sem perdermos esse horizonte da análise crítica das trajetórias sociais dos sujeitos, em escala macro, Bourdieu nos dá pistas para a compreensão das desigualdades sociais e escolares, a exemplo de casos de egressos da EJA, aos apresentarmos traços do capital cultural familiar e escolar. Já Lahire desenvolve uma sociologia à escala individual, em que busca uma atenção maior para a diversidade de experiências de socialização a que o sujeito é submetido, à pluralidade das disposições incorporadas e, por vezes contraditórias, marcando os percursos sociais. Assim, a perspectiva complementar entre Bourdieu e Lahire até é possível, reconhecendo os marcos de distinção conceitual entre um e outro, realizando os prolongamentos críticos. Entretanto, para

repentina, rolava de novo para a planície'. Diante disso, 'Sísifo a empurrava de novo morro acima, coberto de suor, mas em vão."' (SANTOS, 2012, p. 279). este estudo, pela base do material empírico exploratório, há uma aproximação mais efetiva com a base teórica construída por Bourdieu, em termos das posições sociais homólogas de egressos na estrutura social brasileira e por aspectos subjetivos, sentido prático diante da opção pela EJA/EaD, legitimando-a no espaço social mais global como modalidade educacional, por exemplo.

0 estudo mostrou sujeitos assumindo nova posição em relação à escolarização e rompendo, passado algum tempo da sua trajetória de abandono dos estudos, com aspectos que, em princípio, seriam condicionantes para o seu percurso. A formação escolar de um sujeito, em determinada fase da escolarização, com rotina de leitura, tendo aprendido a estudar, a exercitar o raciocínio, foram disposições postas em ação em outro momento da sua trajetória; subjetivamente, a inibição de disposições sociais inadequadas (LAHIRE, 2002) - com relação ao uso de drogas por um egresso - representou a luta do estudante contra uma parte dele. Essas são dimensões em escala micro, muitas vezes invisíveis pelo peso dos aspectos estruturais: a origem social da família, as relações sociais, a condição de ser pobre, estudar na modalidade EJA, por exemplo. Sujeitos que transformaram certas conjunturas e determinantes sociais, superaram dificuldades, retomaram a escolarização, concluíram seus estudos e seguiram adiante, com outros projetos, cursos e outras conquistas. Que força é essa que leva as pessoas a romperem com determinantes sociais?

\section{REFERÊNCIAS}

ABDALLA, Maurício; BARROS, Maria Elizabeth Barros de (org.). Mundo e sujeito: aspectos subjetivos da globalização. São Paulo: Paulus, 2004.

ALMEIDA, Maria Elizabeth Bianconcini de. Educação, ambientes virtuais e interatividade. In: SILVA, Marco (org.). Educação online: teorias, práticas, legislação, formação corporativa. São Paulo: Loyola, 2006. p. 201-215.

ANDRADE, Elaine R. A educação de jovens e adultos e os jovens do "último turno": produzindo out- 
siders. 2004. 223 f. Tese (Doutorado em Educação) - Programa de Pós-Graduação em Educação, Universidade Federal Fluminense (UFF), Niterói, RJ, 2004.

ARAÚJO, Márcia Basília de. Longevidade escolar nos meios populares: disposições e estratégias dos bolsistas de pós-graduação do Programa Internacional de Bolsas de Pós-Graduação da Fundação Ford (International Fellowships Programa). 2015. 127 f. Dissertação (Mestrado em Educação e Formação Humana) - Programa de PósGraduação em Educação, Universidade do Estado de Minas Gerais (UEMG). Belo Horizonte, 2015. Disponível em: http://www.ppgeduc.uemg.br/ wp-content/uploads/2016/06/TD9150815256. pdf. Acesso em: 03 mar. 2017.

ARROYO, Miguel González. Educação de jovensadultos: um campo de direitos e de responsabilidade pública. In: GIOVANETTI, Maria Amélia; GOMES, Nilma Lino; SOARES, Leôncio (org.). Diálogos na educação de jovens e adultos. São Paulo: Autêntica, 2007. p. 19-50.

BLOGSPOT. Educação de jovens e adultos à distância: desafios do aprender. Brasília, DF, 2017. Disponível em: http://www.ejaeadcesas.blogspot. com/p/seja-bem-vindo-este-blog.html. Acesso em: mar. 2019.

BONALDI, Eduardo Vilar. Sistemas e patrimônios de disposições: uma articulação complementar entre Bourdieu e Lahire. In: CONGRESSO LATINOAMERICANO DE SOCIOLOGÍA, 24., 2003, Santiago. Anais [...]. Santiago: ALAS, 2003.

BOURDIEU, Pierre. Meditações pascalinas. Rio de Janeiro: Bertrand, 2001

BOURDIEU, Pierre. Pierre Bourdieu. Entrevistado por Maria Andréa Loyola. Rio de Janeiro: EDUERJ, 2002. (Coleção Pensamento Contemporâneo).

BOURDIEU, Pierre. Escritos de educação. NOGUEIRA, M. A.; CATANI, A. (org.). 9. ed. Petrópolis, RJ: Vozes, 2011.

BOURDIEU, Pierre. Esboço de uma teoria da prática. In: ORTIZ, Renato (org.). A sociologia de Pierre Bourdieu. São Paulo: Olho D’Água, 2013. p. 39-72.

BRAGANÇA, Inês F. de Souza. Histórias de vida e formação de professores: diálogos entre Brasil e Portugal. Rio de Janeiro: UERJ, 2012.

BRASIL. Ministério da Educação. Secretaria de Educação Continuada, Alfabetização e Diversidade. Documento Nacional Preparatório à VI Confe- rência Internacional de Educação de Adultos (VI CONFINTEA). Brasília, DF: MEC, 2009.

BRASIL. Ministério da Educação. Secretaria de Educação Continuada, Alfabetização, Diversidade e Inclusão. Coletânea de textos CONFINTEA Brasil+6: tema central e oficinas temáticas. Brasília, DF: MEC, 2016.

BUARQUE, Cristovam. Globalização sem exclusão: ideias para uma nova modernidade na América Latina. In: Projeto Demos: relatório sobre os princípios democráticos e a governabilidade. Brasília, DF: Unesco, 1997. p. 99-116.

CARRANO, Paulo. Educação de jovens e adultos e juventude: o desafio de compreender os sentidos da presença dos jovens na escola da "segunda chance”. REVEJ@ - Revista de Educação de Jovens e Adultos, Belo Horizonte, v. 1, n. 0, p. 1-108, ago. 2007. Disponível em: http://www.emdialogo. uff.br/sites/default/files/educacao_de_jovens_e_ adultos_e_juventude_-_carrano.pdf. Acesso em: 01 jul. 2016.

CASTEL, Robert. Pierre Bourdieu e a rigidez do mundo. In: ENCREVÉ, Pierre; LAGRAVE, Rose-Marie (coord.). Trabalhar com Bourdieu. Rio de Janeiro: Bertrand Brasil, 2005. p. 351-358.

DENZIN, Norman K.; LINCOLN, Yvonna S. Introdução: a disciplina e a prática da pesquisa qualitativa. In: DENZIN, Norman K.; LINCOLN, Yvonna S. (org.). 0 planejamento da pesquisa qualitativa: teoria e abordagens. Porto Alegre: Artmed, 2006. p. 15-41.

DUARTE, Natália de Souza. Política social: um estudo sobre educação e pobreza. 2012. 260f. Tese (Doutorado em Política Social) - Programa de Pós-Graduação em Política Social, Universidade de Brasília (UnB), Brasília, DF, 2012.

FÁVERO, Osmar. Educação de jovens e adultos: passado de histórias; presente de promessas. In: RIVERO, José; FÁVERO, Osmar. Educação de jovens e adultos na América Latina: direito e desafio de todos. São Paulo: Moderna/Unesco/Fundação Santillana, 2009. p. 55-92.

GARTMAN, David. The strenght of weak program in cultural sociology: a critique of Alexander's critique of Bourdieu. Teory \& Society, n. 36, p. 381-413, 2007. Disponível em: https://www.academia. edu/35716343/The_strength_of_weak_programs_ in_cultural_sociology_A_critique_of_Alexander_s_ critique_of_Bourdieu. Acesso em: maio 2019.

HADDAD, Sérgio; DI PIERRO, Maria Clara. Escolarização de jovens e adultos. Revista Brasi- 
leira de Educação, Rio de Janeiro, n. 14, p. 108-194, jun./ago. 2000. Disponível em: http://educa.fcc. org.br/pdf/rbedu/n14/n14a07.pdf. Acesso em: 01 jul. 2016.

LAHIRE, Bernard. Entrevista com Bernard Lahire. Cronos, Natal, v. 10, n. 2, p. 173-177, jul./dez. 2009. Disponível em: https://periodicos.ufrn.br/cronos/ article/view/3293/2681. Acesso em: 01 jul. 2019.

LAHIRE, Bernard. Homem plural: os determinantes da ação. Petrópolis, RJ: Vozes, 2002.

LAHIRE, Bernard. Patrimônios individuais de disposições: para uma sociologia à escala individual. Sociologia, Problemas e Práticas, Oeiras, Portugal, n. 49, p. 11-42, set. 2005. Disponível em: http://www.scielo.mec.pt/pdf/spp/n49/n49a02. pdf. Acesso em: 01 jul. 2016.

LAHIRE, Bernard. Sucesso escolar nos meios populares: as razões do improvável. São Paulo: Ática, 1997.

LANDINI, Tatiana Savoia. Jogos habituais - sobre a noção de habitus em Pierre Bourdieu e Norbert Elias. Campinas, SP, 2007. Disponível em: http:// www.uel.br/grupoestudo/processoscivilizadores/ portugues/sitesanais/anais10/Artigos_PDF/ Tatiana_Landini.pdf. Acesso em: 01 jul. 2016.

LOBO NETO, Francisco José da Silveira. Regulamentação da educação a distância: caminhos e descaminhos. In: SILVA, Marco (org.). Educação online: teorias, práticas, legislação, formação corporativa. São Paulo: Loyola, 2006. p. 397-414

MONTEIRO, Guilherme Seto; FERREIRA, Mariana Toledo. Entrevista com Bernard Lahire. Plural - Revista do Programa de Pós-Graduação em Sociologia da USP, São Paulo, v. 19.2, p. 153-163, 2012.

MONTESINOS, Jorge Nieto. Governar a globalização. In: Projeto Demos: relatório sobre os princípios democráticos e a governabilidade. Brasília, DF: Unesco, 1997. p. 71-94

NOGUEIRA, Cláudio M. M. Dilemas na análise sociológica de um momento crucial das trajetórias escolares: o processo de escolha do curso superior. 2004. 185 f. Tese (Doutorado em Educação) - Programa de Pós-Graduação em Educação, Universidade Federal de Minas Gerais (UFMG), Belo Horizonte, 2004. Disponível em: http://www.bibliotecadigital.ufmg.br/dspace/ bitstream/handle/1843/FAEC-69WRGU/tese_cl_ udio_marques_martins_nogueira.pdf?sequence=1. Acesso em: 01 jul. 2016.
NOGUEIRA, Maria Alice; NOGUEIRA, Claudio Martins. Bourdieu \& a educação. 3. ed. Belo Horizonte: Autêntica, 2009.

NOGUEIRA, Claudio Marques Martins; NOGUEIRA, Maria Alice. A sociologia da educação de Pierre Bourdieu: limites e contribuições. Educação \& Sociedade, n. 78, p. 15-36, abr. 2002. Disponível em: http://www.scielo.br/pdf/es/v23n78/a03v2378. pdf. Acesso em: 01 jul. 2016.

OLIVEIRA, Marta Kohl. Jovens e adultos como sujeitos de conhecimento e aprendizagem. Revista Brasileira de Educação, São Paulo, n. 12, p. 59-73, set./dez. 1999.

ORTIZ, Renato. Trajetórias e memórias. São Paulo: Brasiliense, 2010.

REIS, Geraldo Ananias. Jovens e adultos na educação a distância: uma perspectiva disposicionalista. 2014. 152f. Dissertação (Mestrado em Educação) - Programa de PósGraduação em Educação da Faculdade de Educação, Universidade de Brasília (UnB), Brasília, DF, 2014. Disponível em: http://repositorio. unb.br/bitstream/10482/17730/1/2014_ GeraldoAnaniasReis.pdf. Acesso em: maio 2019.

RIVERO, José. Alfabetização e educação de jovens e adultos na América Latina, direito humano fundamental e fator essencial de equidade. In.: RIVERO, José; FÁVERO, Osmar. Educação de jovens e adultos na América Latina: direito e desafio de todos. São Paulo: Moderna/Unesco/Fundação Santillana, 2009. p. 9-54.

ROCHA, Décio; DAHER, Maria Del Carmen; SANT'ANNA, Vera Lúcia de Albuquerque. A entrevista em situação de pesquisa acadêmica: reflexões numa perspectiva discursiva. Polifonia, v. 8, n. 8, 2004. Disponível em: http://cpd1.ufmt. $\mathrm{br} / \mathrm{meel} /$ arquivos/artigos/24.pdf. Acesso em: 01 jul. 2016.

SANTOS, Claudecir dos. A educação e os mitos no século XXI: Narciso, Eco e Sísifo estão na escola. Cadernos do Aplicação, Porto Alegre, v. 25, n. 2, p.271282, jul./dez. 2012. Disponível em: http://seer. ufrgs.br/index.php/CadernosdoAplicacao/article/ view/23942/29308. Acesso em: 10 nov. 2014.

SANTOS, Edméa. Cibercultura: o que muda na educação. Boletim Salto para o Futuro, ano XXI, v. 3, p. 5-9, 2011. Disponível em: http:// cdnbi.tvescola.org.br/resources/VMSResources/ contents/document/publicationsSeries/212448c ibercultura.pdf. Acesso em: 17 jul. 2016. 
SETTON, Maria da Graça Jacintho. Um novo capital cultural: pré-disposições e disposições à cultura informal nos seguimentos com baixa escolaridade. Educação \& Sociedade, Campinas, SP, v. 26, n. 90, p. 77-105, jan./abr. 2005. Disponível em: http:// www.scielo.br/pdf/\%0D/es/v26n90/a04v2690. Acesso em: 1 jul. 2016.

SILVA, Edna Lúcia da; MENEZES, Estera Muszkat. Metodologia da pesquisa e elaboração de dissertação. 3. ed. rev. atual. Florianópolis: Laboratório de Ensino a Distância da UFSC, 2001. Disponível em: http://tccbiblio.paginas.ufsc.br/ files/2010/09/024_Metodologia_de_pesquisa_e_ elaboracao_de_teses_e_dissertacoes1.pdf. Acesso em: 23 out. 2013.
SODRÉ, M. Mídia e cidadania. In: ESCOSTEGUY, Ana Carolina D. (org.). Comunicação, cultura e mediações tecnológicas. Porto Alegre: EDIPUCRS, 2006. p.37-44.

SOUSA, Carlos Alberto Lopes de. A pesquisa no ensinar e aprender em e no entorno dos ambientes conectados virtualmente e presencialmente: riscos e potencialidades. In: FERNANDES, Maria Lídia Bueno; DECONTO, Neuza Maria; LOPES, Ruth Maria de Faria (org.). Tessituras e tramas da licenciatura em pedagogia a distância na FE/UnB. Brasília, DF: Editora da UnB, 2014. p. 175-200.

TRIVINÕS, Augusto N. S. Introdução à pesquisa em ciências sociais: a pesquisa qualitativa em educação. 1. ed. 20 reimpr. São Paulo: Atlas, 2011.

Recebido em: 28/03/2017

Aprovado em: 15/07/2019 